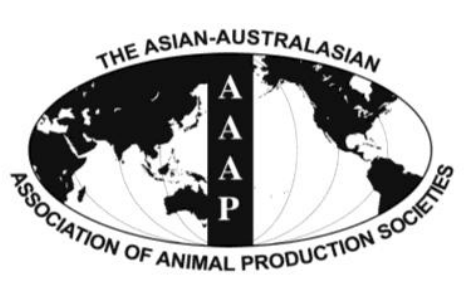

Open Access

Asian Australas. J. Anim. Sci.

Vol. 27, No. 9 : 1303-1310 September 2014

http://dx.doi.org/10.5713/ajas.2014.14087

Www.ajas.info

pISSN 1011-2367 elSSN 1976-5517

\title{
Effects of Dietary Garlic Powder on Growth, Feed Utilization and Whole Body Composition Changes in Fingerling Sterlet Sturgeon, Acipenser ruthenus
}

\author{
Dong-Hoon Lee, Seong-Ryul Lim, Jung-Jo Han, Sang-Woo Lee, Chang-Six Ra ${ }^{1}$, and Jeong-Dae Kim ${ }^{1}$ * \\ Gyeonggi Province Maritime and Fisheries Research Institute, Yangpyeong 476-841, Korea
}

\begin{abstract}
A 12 week growth study was carried out to investigate the supplemental effects of dietary garlic powder (GP) on growth, feed utilization and whole body composition changes of fingerling sterlet sturgeon Acipenser ruthenus (averaging weight, 5.5 g). Following a 24-h fasting, 540 fish were randomly distributed to each of 18 tanks (30 fish/tank) under a semi-recirculation freshwater system. The GP of $0.5 \%$ (GP0.5), $1 \%$ (GP1), 1.5\% (GP1.5), 2\% (GP2) and 3\% (GP3) was added to the control diet (GP0) containing $43 \%$ protein and $16 \%$ lipid. After the feeding trial, weight gain (WG) of fish fed GP1.5, GP2 and GP3 were significantly higher (p<0.05) than those of fish fed GP0, GP0.5 and GP1. Feed efficiency and specific growth rate (SGR) showed a similar trend to WG. Protein efficiency ratio of fish fed GP1.5, GP2, and GP3 were significantly higher $(\mathrm{p}<0.05)$ than those of fish groups fed the other diets. A significant difference $(\mathrm{p}<0.05)$ was found in whole body composition (moisture, crude protein, crude lipid, ash, and fiber) of fish at the end of the experiment. Significantly higher $(\mathrm{p}<0.05)$ protein and lipid retention efficiencies (PRE and LRE) were also found in GP1.5, GP2, and GP3 groups. Broken-line regression model analysis and second order polynomial regression model analysis relation on the basis of SGR and WG indicated that the dietary optimal GP level could be greater than $1.77 \%$ and $1.79 \%$, but less than $2.95 \%$ and $3.18 \%$ in fingerling sterlet sturgeon. The present study suggested that dietary GP for fingerling sterlet sturgeon could positively affect growth performance and protein retention. (Key Words: Acipenser ruthenus, Garlic Powder, Protein Retention, Weight Gain, Feed Efficiency, Body Composition)
\end{abstract}

\section{INTRODUCTION}

Fish is a highly nutritive and rich source of animal proteins. For the improvement of fisheries and to achieve maximum yields from resources of fresh water, it is necessary to provide an artificial feed, by which fish grow rapidly and attain maximum weight in shortest possible time (Bhosale et al., 2010). One approach is to include new substances into fish diets to improve feed conversion efficiency or elevate general conditions for fish growth and maintenance (Fernández-Navarro et al., 2006). Plants are natural source of safer and cheaper chemicals. Beneficial

\footnotetext{
* Corresponding Author: Jeong-Dae Kim. Tel: +82-33-2508634, Fax: +82-33-2555482, E-mail: menzang@gmail.com

${ }^{1}$ College of Animal Life Sciences, Kangwon National University, Chuncheon 200-701, Korea.

Submitted Feb. 6, 2014; Revised Apr. 23, 2014; Accepted May 28, 2014
}

effects of bioactive plant substances in animal nutrition may include the stimulation of appetite and feed intake, the improvement of endogenous digestive enzyme secretion, activation of immune responses and antibacterial, antiviral and antioxidant actions (Citarasu, 2010).

Plant products have been reported to promote various activities like anti-stress, growth promotion, appetite stimulation and immunostimulation in aquaculture practices (Citarasu et al., 2001,2002; Sivaram et al., 2004). Garlic (Allium sativum) is a perennial bulb-forming plant that belongs to the genus Allium in the family Liliaceae. Garlic has been a subject of considerable interest for centuries as a flavouring agent, traditional medicine, and a functional food to enhance physical and mental health. Garlic was studied in different forms of extracts: aqueous, ethanol and dried powder (Shin and Kim, 2004). It contains a variety of organosulfur compounds such as allicin, ajoene, S- 
allylcysteine, diallyl disulfide, S-methylcysteine sulfoxide and S-allylcysteine (Chi et al., 1982). A wide array of beneficial effects of garlic such as antihypertensive, antihyperlipidemic, antimicrobial, hypoglycaemic, anticancer, antidote (for heavy metal poisoning), anticarcinogenic, hepatoprotective and immunomodulation have been reported by several researchers (Foushee et al., 1982; Macmahon and Vargus 1993; Agarwal, 1996; Agusti, 1996; Bordia et al., 1996; Yeh and Liu, 2001). Studies on garlic as an alternative growth promoter in livestock production were conducted and its beneficial effects on growth, digestibility and carcass traits have been reported (Bampids et al., 2005; Tatara et al., 2008). Dietary garlic as a growth promoter in Nile tilapia (Oreochromis niloticus) improved body weight gain (WG), feed intake and feed efficiency (FE) (Diab et al., 2002; Shalaby et al., 2006).

In Korea, sturgeon aquaculture began in 1996 with the main species of sterlet sturgeon (Acipenser ruthenus), Siberian (A. baeri), Russian (A. gueldenstaedti), Stellate (A. stellatus) and hybrid called bester (beluga femalexsterlet male). The sterlet is freshwater species which very rarely ascends the brackish water of rivers (Krayushina, 2006).

Our previous research suggested dietary garlic for juvenile sterlet sturgeon (60 to $100 \mathrm{~g}$ ) could positively affect growth performance (Lee et al., 2012), but no trial was conducted to study the effect of dietary garlic powder (GP) for fingerling sterlet sturgeon to date. Therefore, this study was designed to investigate the effects of garlic powder on growth performance and whole body composition changes of the fish.

\section{MATERIALS AND METHODS}

\section{Experimental design and diets}

Fingerling sterlet sturgeons (Acipenser ruthenus) were obtained from Gyeonggi Province Maritime and Fisheries Research Institute, Gyeonggido, Korea. This experiment was designed to determine the optimum levels of GP as a growth promoter and carried out to investigate the supplemental effect of dietary GP on whole body composition changes of fingerling sterlet sturgeon during 12 weeks. Six groups (three replicates/group) of 540 fish of a mean body weight of $5.5 \mathrm{~g}$ selected from 2,500 fish were randomly allotted to each of 18 tanks $(2 \times 1 \times 0.4 \mathrm{~m})$. Fish were cultured in semi-recirculation freshwater system. Water temperature and dissolved oxygen levels were kept at $21 \pm 1^{\circ} \mathrm{C}$ and over $6 \mathrm{mg} \mathrm{O} / \mathrm{L}$, respectively. Flow rate was adjusted at a minimum level of $10 \mathrm{~L} / \mathrm{min}$.

Composition and proximate analysis of the experiment diets are shown Table 1 . The GP of $0.5 \%, 1 \%, 1.5 \%, 2 \%$, and $3 \%$ each was added to the basal diet (GP0) containing $43 \%$ protein and $16 \%$ lipid and the diets were designated as GP0.5, GP1, GP1.5, GP2, and GP3. Experimental diets were manufactured at the size of $1.5 \mathrm{~mm}$ by a twin extruder

Table 1. Ingredient composition and chemical analysis of the experimental diets ${ }^{1}$

\begin{tabular}{|c|c|c|c|c|c|c|}
\hline Ingredients & GP0 & GP0.5 & GP1 & GP1.5 & GP2 & GP3 \\
\hline LT fish meal & 20 & 20 & 20 & 20 & 20 & 20 \\
\hline Fish meal & 15 & 15 & 15 & 15 & 15 & 15 \\
\hline Wheat flour & 20 & 20 & 20 & 20 & 20 & 20 \\
\hline Corn gluten meal & 0 & 0 & 0 & 0 & 0 & 0 \\
\hline Soybean meal & 22 & 22 & 22 & 22 & 22 & 22 \\
\hline Squid liver powder & 2 & 2 & 2 & 2 & 2 & 2 \\
\hline Lecithin & 1 & 1 & 1 & 1 & 1 & 1 \\
\hline Choline & 0.2 & 0.2 & 0.2 & 0.2 & 0.2 & 0.2 \\
\hline Betaine & 0.2 & 0.2 & 0.2 & 0.2 & 0.2 & 0.2 \\
\hline Vitamin mix & 0.1 & 0.1 & 0.1 & 0.1 & 0.1 & 0.1 \\
\hline Mineral mix & 0.1 & 0.1 & 0.1 & 0.1 & 0.1 & 0.1 \\
\hline Fish oil & 9.4 & 9.4 & 9.4 & 9.4 & 9.4 & 9.4 \\
\hline Filler as rice bran & 10 & 9.5 & 9 & 8.5 & 8 & 7 \\
\hline Garlic powder ${ }^{2}$ & 0 & 0.5 & 1 & 1.5 & 2 & 3 \\
\hline \multicolumn{7}{|c|}{ Chemical composition $(\%, \mathrm{DM})^{3}$} \\
\hline Protein & 43.8 & 43.7 & 43.5 & 42.4 & 43.2 & 42.8 \\
\hline Lipid & 15.5 & 15.5 & 15.6 & 16.1 & 16.0 & 16.1 \\
\hline Ash & 9.7 & 9.8 & 9.8 & 9.4 & 9.3 & 9.7 \\
\hline Fiber & 6.5 & 6.4 & 5.9 & 6.1 & 6.0 & 5.4 \\
\hline Gross energy $(\mathrm{kJ} / \mathrm{g})$ & 22.6 & 22.7 & 21.4 & 21.3 & 21.2 & 21.0 \\
\hline
\end{tabular}

GP, garlic powder; LT, low temperature; DM, dry matter.

${ }^{1}$ All ingredients were provided with Cargill Agri Purina Ltd., Korea.

${ }^{2}$ Obtained from local market at Gyeonggi Province, in Korea.

${ }^{3}$ Values are means of three determinations. 
(Model ATX-2, Fesco Precision Co., Daegu, Korea) in Shinjang-Bios Company in Korea. Diets were fed by hand at the rate of $4 \%$ to $5 \%$ of fish body weight per day at 08:00, 13:00, and 18:00 for 12 weeks. All diets were stored at $-20^{\circ} \mathrm{C}$ prior to use.

\section{Sample collection and analysis}

At the end of the feeding trial, fish were anesthetized with AQUI-S (New Zealand Ltd., Lower Hutt, NZ) and then weighed as total fish weight of each replicate within groups and counted for calculation of WG, FE, specific growth rate (SGR), protein efficiency ratio (PER) and survival rate. Six fish (two fish per tank) from each group were selected at similar weight to determine hepatosomatic index (HSI) and condition factor (CF). Fifteen fish (five fish per tank) from each group were selected to analyze whole-body proximate composition. Chemical analyses of diets and fish whole body were performed by the standard procedure of AOAC (1995) for moisture, crude protein and crude ash. Crude lipid was determined using the Soxtec system 1046 (Tecator AB, Hoganas, Sweden) after freezedrying the samples for 12 hours. Crude fiber was measured as loss on ignition of dried lipid free residues after digestion with $1.25 \% \quad \mathrm{H}_{2} \mathrm{SO}_{4}$ and $1.25 \% \mathrm{NaOH}$ (FOSS instrument, Hoganas, Sweden) and gross energy was determined using as automatic adiabatic bomb calorimeter (PARR instrument, USA).

\section{Statistical analysis}

Data (WG, FE, SGR, PER, HIS, CF, whole body compositions and retention efficiency) were analyzed using one-way analysis of variance (ANOVA) and significant differences among treatment means were compared using Duncan's multiple range test (Duncan, 1955). Broken-line analysis (Robbins et al., 1979) was used to estimate the optimum dietary GP levels and the second-order polynomial regression analysis (Zeitoun et al., 1976) was introduced to the optimum dietary GP requirement of fingerling sterlet sturgeon. Significance was tested at 5\% level and all statistical analyses were carried out using the SPSS Version 10 (SPSS, Michigan Avenue, Chicago, IL, USA).

\section{RESULTS}

\section{Growth performance}

At the end of the $12 \mathrm{wk}$ feeding, WG, FE, SGR, PER, HSI, and CF and survival of fingering sterlet sturgeon fed the experimental diets were determined and shown in Table 2. Fish fed GP1, GP1.5, GP2, and GP3 exhibited significant improvement in WG, FE, SGR, PER, and CF as compared to those of fish fed the control diet GP0 $(\mathrm{p}<0.05)$. Final weight of fish was the highest in fish fed GP3 (30.2 g), while the lowest $(25.6 \mathrm{~g})$ was found in fish fed GP0. The $\mathrm{CF}(0.52)$ of fish fed GP2 was significantly higher $(\mathrm{p}<0.05)$ than that of fish fed diet, it was, however, not significantly different from that of fish fed GP3 ( $p>0.05)$. The highest HSI $(2.08 \%)$ was found in fish fed GP0 among treatments $(\mathrm{p}<0.05)$. Although fish fed GP3 showed the lowest HSI of $1.71 \%$ among fish groups, it was not significantly different ( $p>0.05$ ) from three other groups (GP1, GP 1.5, and GP2). No mortality was recorded in all fish groups during the experimental period. Based on the on-way ANOVA, broken-line regression model analysis and second order polynomial regression model analysis relation on SGR and WG, the optimum dietary p level (\%) could be greater than $1.77 \%$ and $1.79 \%$ (Figures 1 and 2), but less than $2.95 \%$ and $3.18 \%$ in fingerling sterlet sturgeon under our experimental conditions (Figures 3 and 4), respectively.

Table 2. Growth performance of fingerling sterlet sturgeon fed diets without (GP0) or with (GP0.5, GP1, GP1.5, GP2 and GP3) garlic powder diets for $12 \mathrm{wk}^{1}$

\begin{tabular}{|c|c|c|c|c|c|c|c|}
\hline \multirow{2}{*}{ Growth performance } & \multicolumn{6}{|c|}{ Diets } & \multirow{2}{*}{ p-value } \\
\hline & GP0 & GP0.5 & GP1 & GP1.5 & GP2 & GP3 & \\
\hline Initial average weight (g) & $5.50 \pm 0.03$ & $5.46 \pm 0.02$ & $5.51 \pm 0.05$ & $5.48 \pm 0.02$ & $5.53 \pm 0.03$ & $5.51 \pm 0.02$ & \\
\hline Final average weight (g) & $25.64 \pm 1.12$ & $26.14 \pm 0.28$ & $27.01 \pm 0.39$ & $29.60 \pm 0.25$ & $30.16 \pm 0.20$ & $30.18 \pm 0.21$ & \\
\hline $\mathrm{WG}(\%)^{2}$ & $366.4 \pm 2.3^{c}$ & $379.2 \pm 4.3^{\mathrm{b}}$ & $390.1 \pm 5.9^{b}$ & $440.4 \pm 6.2^{\mathrm{a}}$ & $445.0 \pm 3.7^{\mathrm{a}}$ & $448.0 \pm 3.1^{\mathrm{a}}$ & $<0.001$ \\
\hline $\mathrm{FE}(\%)^{3}$ & $69.3 \pm 3.7^{\mathrm{c}}$ & $70.9 \pm 0.5^{\mathrm{bc}}$ & $73.2 \pm 1.2^{\mathrm{b}}$ & $82.0 \pm 1.3^{\mathrm{a}}$ & $84.0 \pm 0.9^{\mathrm{a}}$ & $84.2 \pm 0.4^{\mathrm{a}}$ & $<0.001$ \\
\hline $\operatorname{SGR}(\%)^{4}$ & $1.83 \pm 0.04^{\mathrm{c}}$ & $1.87 \pm 0.01^{\mathrm{bc}}$ & $1.89 \pm 0.01^{\mathrm{b}}$ & $2.01 \pm 0.01^{\mathrm{a}}$ & $2.02 \pm 0.01^{\mathrm{a}}$ & $2.02 \pm 0.01^{\mathrm{a}}$ & 0.001 \\
\hline $\mathrm{PER}^{5}$ & $1.62 \pm 0.09^{\mathrm{b}}$ & $1.62 \pm 0.01^{\mathrm{b}}$ & $1.68 \pm 0.03^{b}$ & $1.93 \pm 0.03^{\mathrm{a}}$ & $1.94 \pm 0.02^{\mathrm{a}}$ & $1.97 \pm 0.01^{\mathrm{a}}$ & 0.003 \\
\hline $\operatorname{HSI}(\%)^{6}$ & $2.08 \pm 0.13^{\mathrm{a}}$ & $1.87 \pm 0.05^{\mathrm{b}}$ & $1.81 \pm 0.04^{\mathrm{bc}}$ & $1.83 \pm 0.08^{\mathrm{bc}}$ & $1.74 \pm 0.09^{\mathrm{c}}$ & $1.71 \pm 0.11^{\mathrm{c}}$ & 0.001 \\
\hline $\mathrm{CF}^{7}$ & $0.36 \pm 0.04^{\mathrm{c}}$ & $0.43 \pm 0.03^{\mathrm{bc}}$ & $0.42 \pm 0.04^{\mathrm{bc}}$ & $0.42 \pm 0.06^{b c}$ & $0.52 \pm 0.08^{\mathrm{a}}$ & $0.44 \pm 0.07^{\mathrm{ab}}$ & 0.001 \\
\hline Survival rate $(\%)$ & 100 & 100 & 100 & 100 & 100 & 100 & \\
\hline
\end{tabular}

GP, garlic powder; WG, weight gain; FE, feed efficiency; SGR, specific growth rate; PER, protein efficiency ratio; HSI, hepatosomatic index; CF, condition factor; SE, standard error; DM, dry matter.

${ }^{1}$ Means of three replicates groups, values are presented as mean \pm SE. Means in each row with different superscripts are significantly different $(\mathrm{p}<0.05)$.

${ }^{2} \mathrm{WG}(\%)=[$ final weight $(\mathrm{g})-$ initial weight $(\mathrm{g})] \times 100 /$ initial weight $(\mathrm{g}) .{ }^{3} \mathrm{FE}(\%)=$ wet weight gain $(\mathrm{g}) \times 100 / \mathrm{feed}$ intake $(\mathrm{g}, \mathrm{DM})$.

${ }^{4}$ SGR $(\%)=\{[\ln$ final weight $(\mathrm{g})-\ln$ initial weight $(\mathrm{g})] /$ days $\} \times 100 .{ }^{5}$ PER $=$ wet weight gain $(\mathrm{g}) /$ protein intake $(\mathrm{g}, \mathrm{DM})$.

${ }^{6} \mathrm{HSI}(\%)=$ liver weight $(\mathrm{g}) \times 100 /$ body weight $(\mathrm{g}) .{ }^{7} \mathrm{CF}=\left[\right.$ fish weight $(\mathrm{g}) /$ fish length $\left.(\mathrm{cm})^{3}\right] \times 100$. 


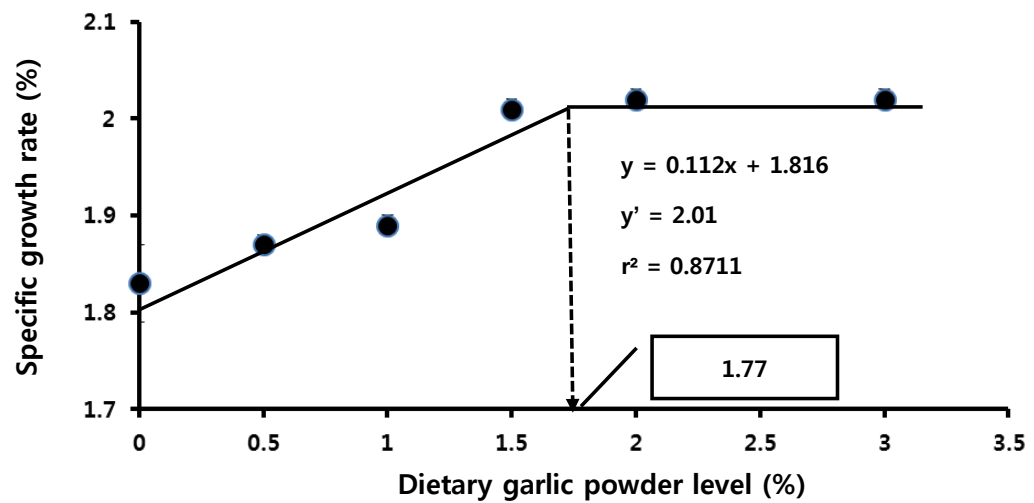

Figure 1. Broken-line analysis on specific growth rate of fingerling sterlet sturgeon to dietary garlic powder levels.

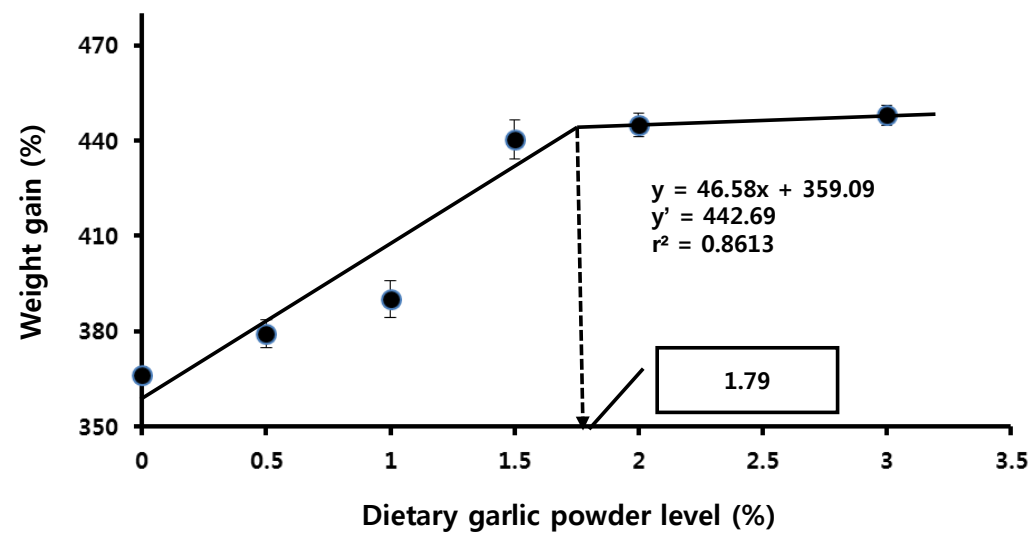

Figure 2. Broken-line analysis on weight gain of fingerling sterlet sturgeon to dietary garlic powder levels.

\section{Whole body compositions}

The whole body proximate composition of initial and final fingerling sturgeon fed diets without (GP0) or with (GP0.5, GP1, GP1.5, GP2, and GP3) GP during 12 weeks is shown in Table 3. Moisture ranged from $75.1 \%$ (GP1.5) to $77.5 \%$ (GP0.5) among fish groups, while that of initial fish was $84.9 \%$. Crude protein and lipid ranged from $13.1 \%$ (GP0) to $15.1 \%$ (GP1.5) and from $5.6 \%$ (GP3) to $6.7 \%$ (GP0), respectively. Fish fed GP3 showed the highest ash content $(3.3 \%)$, while that of fish fed GP0.5 showed the lowest value $(2.5 \%)$. Fiber content ranged from $1.2 \%$ (GP1) to $2.2 \%$ (GP1.5). The proximate composition was significantly different $(\mathrm{p}<0.05)$ among the six experimental fish groups. Protein retention efficiency (PRE) varied from $22.9 \%(\mathrm{GP} 0.5)$ to $31.2 \%(\mathrm{GP} 1.5)$ and lipid retention efficiency (LRE) from $33.2 \%$ (GP1) to $39.1 \%$ (GP0), which were also significantly different $(\mathrm{p}<0.05)$ among fish groups.

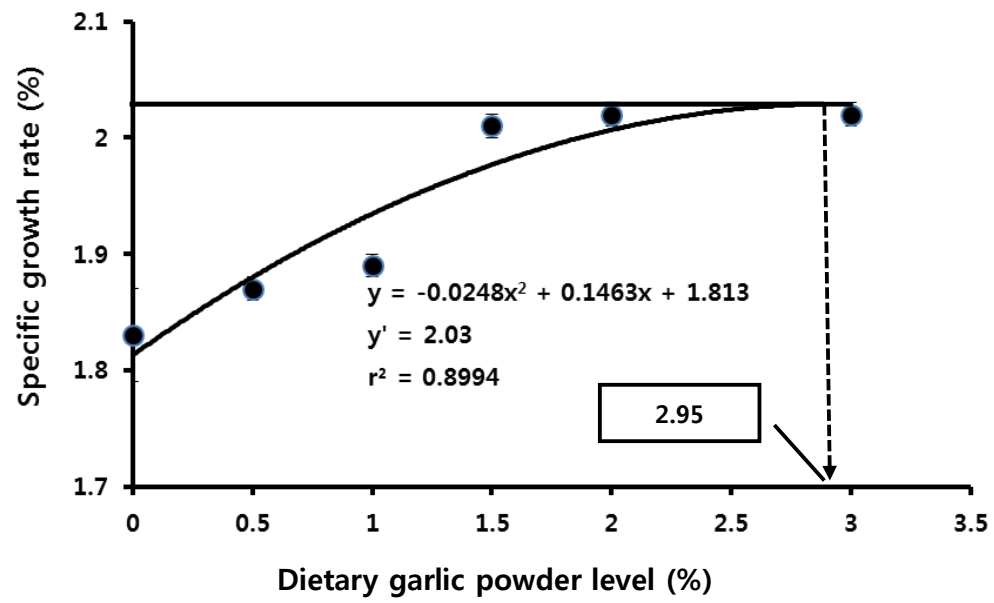

Figure 3. The second order polynomial analysis on specific growth rate of fingerling sterlet sturgeon to dietary garlic powder levels. 


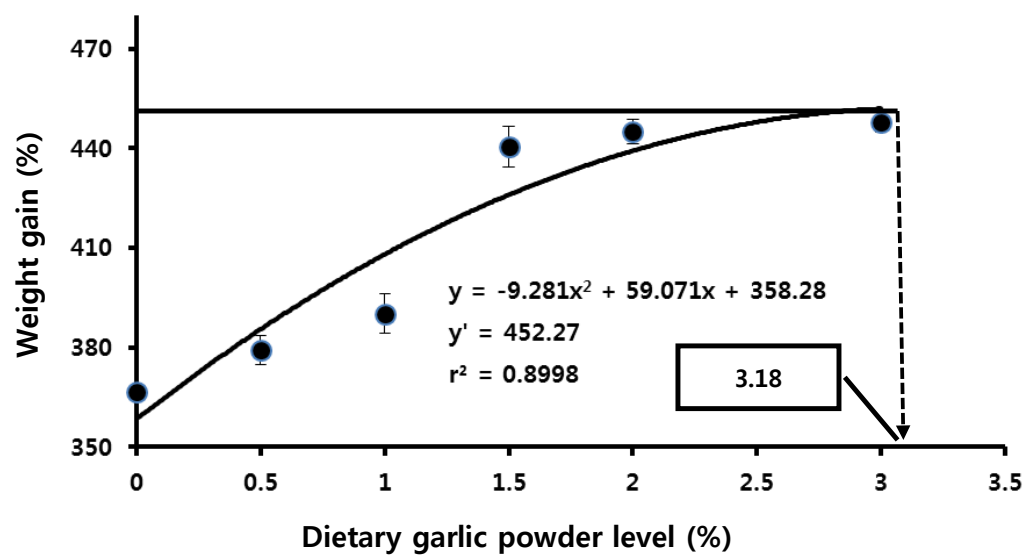

Figure 4. The second order polynomial analysis on weight gain of fingerling sterlet sturgeon to dietary garlic powder levels.

\section{DISCUSSION}

Hung et al. (1998) carried out a growth trial for white sturgeon having $72 \mathrm{~g}$ body weight. They fed fish one of seven commercial salmonid diets or a purified diet for $8 \mathrm{wk}$. These diets contained $5.9 \%$ to $8.3 \%$ moisture, $31.5 \%$ to $51.4 \%$ crude protein, $7.6 \%$ to $19.4 \%$ lipid and $3.8 \%$ to $11.7 \%$ ash. The best growth and FE was obtained from a diet with $4.5 \%$ moisture, $51.4 \%$ crude protein, $18.0 \%$ lipid and $11.7 \%$ ash. However, none of the detailed data was reported on the optimal levels of the remaining nutritive components in the feeds for fingerling sterlet sturgeon (over $5.5 \mathrm{~g}$ ). Lim (2009) reported that the optimum dietary protein requirement level for fingerling sterlet sturgeon (7 to $40 \mathrm{~g}$ ) could be above $44.3 \%$ with the optimum dietary protein to energy ratio of $21.9 \mathrm{mg}$ protein/kJ diet. The graded levels of GP were incorporated into the diet GP0 to investigate dietary protein sparing and the addition of GP showed a significant improvement in WG, FE, SGR, and PER.

Several herbs such as garlic, onion, marjoram, caraway, basil, anise, fennel, licorice, black seed and fenugreek have been tested for growth promoting activities (Jayaprakas and
Eupharsia, 1996; Citarasu et al., 2002; Sivaram et al., 2004), feed conversion (Shalaby et al., 2003; El-Darkar et al., 2004a,b; Shalaby, 2004), and improvement of protein digestibility and energy retention (El-Dakar et al., 2004a,b) in aquatic animals. Results in Table 2 are in agreement with that reported by Soltan and El-Laithy (2008) who reported that the incorporation of garlic in diets for growing Nile tilapia significantly improved WG and SGR. Shalaby et al. (2006) also reported a significant increase in WG, FE, PER, and SGR of Nile tilapia fed diet containing 3\% GP. Similarly, Diab et al. (2002) mentioned feeding diet with $2.5 \%$ garlic resulted in the highest growth performance in $O$. niloticus. In the same species, Abou-Zeid (2002) found a positive improvement in biomass and SGR with garlic supplementation. Metwally (2009) also mentioned that the best performance was obtained in Nile tilapia fed diet with $3.2 \%$ GP. A significant increase in growth, feed conversion and protein efficiency was shown in rainbow trout when fed diet with $1.0 \%$ garlic (Nya and Austin, 2009). Abdel-Hakim et al. (2010) reported that incorporation of garlic into Nile tilapia diets (diet with fresh garlic $3 \mathrm{~g}$ per $\mathrm{kg}$ ) resulted in significant improvement in WG, feed conversion, protein efficiency and CF. Protein efficiency ratio and FE are

Table 3. Proximate composition of whole body of fingerling sterlet sturgeon fed without (GP0) or with (GP0.5, GP1, GP2, and GP3) garlic powder diets for $12 \mathrm{wk}$ (\%, as-is basis) ${ }^{1}$

\begin{tabular}{lccccccc}
\hline Treatments & Moisture & Crude protein & Crude lipid & Ash & Fiber & PRE $^{2}$ & LRE $^{3}$ \\
\hline Initial & $84.90 \pm 0.32$ & $10.22 \pm 0.09$ & $1.19 \pm 0.05$ & $2.42 \pm 0.02$ & $0.18 \pm 0.01$ & & \\
GP0 & $77.30 \pm 0.05^{\mathrm{a}}$ & $13.06 \pm 0.17^{\mathrm{d}}$ & $6.71 \pm 0.07^{\mathrm{a}}$ & $3.01 \pm 0.09^{\mathrm{b}}$ & $2.05 \pm 0.08^{\mathrm{b}}$ & $23.2 \pm 0.4^{\mathrm{c}}$ & $39.1 \pm 0.5^{\mathrm{a}}$ \\
GP0.5 & $77.47 \pm 0.27^{\mathrm{a}}$ & $13.32 \pm 0.11^{\mathrm{d}}$ & $5.99 \pm 0.05^{\mathrm{b}}$ & $2.45 \pm 0.06^{\mathrm{c}}$ & $1.75 \pm 0.07^{\mathrm{c}}$ & $22.9 \pm 0.2^{\mathrm{c}}$ & $33.4 \pm 0.2^{\mathrm{d}}$ \\
GP1 & $76.88 \pm 0.25^{\mathrm{ab}}$ & $13.99 \pm 0.03^{\mathrm{c}}$ & $6.05 \pm 0.02^{\mathrm{b}}$ & $2.87 \pm 0.08^{\mathrm{b}}$ & $1.19 \pm 0.06^{\mathrm{d}}$ & $24.3 \pm 1.2^{\mathrm{b}}$ & $33.2 \pm 1.4^{\mathrm{d}}$ \\
GP1 1.5 & $75.11 \pm 0.48^{\mathrm{c}}$ & $15.06 \pm 0.44^{\mathrm{a}}$ & $5.84 \pm 0.09^{\mathrm{c}}$ & $3.24 \pm 0.10^{\mathrm{a}}$ & $2.21 \pm 0.04^{\mathrm{a}}$ & $31.2 \pm 0.5^{\mathrm{a}}$ & $34.1 \pm 0.5^{\mathrm{cd}}$ \\
GP2 & $75.50 \pm 0.01^{\mathrm{c}}$ & $14.82 \pm 0.07^{\mathrm{a}}$ & $5.62 \pm 0.14^{\mathrm{d}}$ & $2.93 \pm 0.15^{\mathrm{b}}$ & $2.04 \pm 0.06^{\mathrm{b}}$ & $30.8 \pm 0.3^{\mathrm{a}}$ & $34.7 \pm 0.3^{\mathrm{c}}$ \\
GP3 & $76.29 \pm 0.64^{\mathrm{b}}$ & $14.49 \pm 0.11^{\mathrm{b}}$ & $5.59 \pm 0.05^{\mathrm{d}}$ & $3.27 \pm 0.01^{\mathrm{a}}$ & $1.27 \pm 0.04^{\mathrm{d}}$ & $30.4 \pm 0.1^{\mathrm{a}}$ & $36.7 \pm 0.1^{\mathrm{b}}$ \\
p-value & 0.003 & $<0.001$ & 0.001 & 0.002 & $<0.001$ & $<0.001$ & 0.001 \\
\hline
\end{tabular}

GP, garlic powder; PRE, Protein retention efficiency; LRE, lipid retention efficiency; SE, standard error.

${ }^{1}$ Values are means \pm SE of three replicates with 2 determinations per replicate for each final group. Means with different superscripts in the same row are significantly different $(\mathrm{p}<0.05)$. ns, non significant $(\mathrm{p}>0.05)$.

${ }^{2}$ PRE $(\%)=$ body protein gain $(\mathrm{g}) /$ dry protein intake $(\mathrm{g}) \times 100 .{ }^{3} \mathrm{LRE}(\%)=$ body lipid gain $(\mathrm{g}) /$ dry lipid intake $(\mathrm{g}) \times 100$ 
utilized as quality indicators for fish diets and amino acid balance. Therefore, these factors are used to evaluate protein utilization and turnover (Shalaby et al., 2006). The present results are also in agreement with those obtained by Khattab et al. (2004) who found that the diet of Biogen increased feed intake, improved feed conversion ratio (FCR) and PER in tilapia. In contrast to these results, however, Sahu et al. (2007) reported that SGR and FCR in fish (Labeo rohita) fed diet with $0.5 \%$ and $1 \%$ GP was not significantly different from those of the control. In livestock, a few studies suggested that garlic did not affect growth performance (Horton et al., 1991; Freitas et al., 2001; Bampidis et al., 2005) because of the pungent smell which may lead to lower diet palatability. Jegede (2012) reported that apparent protein digestibility was significantly improved from $71.2 \%$ for control diet to $85.2 \%$ for a diet with $2 \%$ garlic. Khalil et al. (2001) mentioned that garlic contains allicin, which promotes the performance of the intestinal flora, thereby improving digestion and enhancing the utilization of energy, leading to improved growth. Wanapat et al. (2008) found significantly higher digestibility, absorption and retention of $\mathrm{N}$ in GP supplemented groups compared to control group. Those results also accord with our present finding that sturgeons fed GP1.5, GP2.0 and GP3.0 had higher N utilization (PRE, \%) than other groups. From these results, it was concluded that the addition of GP of $1.79 \%$ to $3.18 \%$ was optimal for growth performance of fingerling sterlet sturgeon and revealed that addition of GP could spare dietary protein in terms of growth and feed utilization, although protein digestibility was not determined.

The HSI provides an indication of the status of energy reserve in an animal. As the liver is a target for the metabolism in the fish body, the liver index (HSI) is a useful biomarker to detect the hazardous effects of environmental factors (Pait and Nelson, 2003). The present results showed that fish groups fed GP containing diets had significantly lower HSI than that of fish group fed GP0. Our results are in agreement with the finding of Metwally (2009) who reported that diets fed for three months containing different forms of garlic, natural garlic (40 g per $\mathrm{kg}$ diet), garlic oil capsules (250 mg per $\mathrm{kg}$ diet $)$ significantly decreased HSI of fingerling Nile tilapia. In contrast, Shalaby et al. (2006) showed that incorporation of garlic into Nile tilapia diets $(10,20,30$, and $40 \mathrm{~g}$ per $\mathrm{kg}$ diet) had no significant effects on HSI. Al-Salahy and Mahmoud (2003) reported that garlic caused significant hypolipidaemia in response to repeated doses, accompanied by a decrease in liver total lipids and a significant rise in white muscle total lipids. In the present study, HSI was lower in fish groups fed diets containing higher GP (GP2 and GP3) than that of the group fed GP0 which showed the lowest growth performance. Therefore, such observed hepatomegaly in the GP0 group may partially reflect that HSI level deviates from the normal range in fingerling sterlet sturgeon because of high dietary lipid and that GP administration (GP diets) may lead to a significant decrease in liver lipid.

Dietary lipids are important nutrient affecting energy production and essential for growth and development in most of fish. But, fish are known to utilize protein preferentially to lipid or carbohydrate as an energy source. In our previous study (Lee et al., 2012), lipid content in whole body of juvenile sterlet sturgeon fed diet with $0.5 \%$ garlic extract was significantly higher $(6.1 \%)$ than that $(5.4 \%)$ of fish fed control. However, in the present study the higher dietary GP significantly decreased body lipid from $6.71 \%$ (GP0) to $5.59 \%$ (GP3). In addition, when compared to our previous study (Lee et al., 2012), PRE was higher and LRE (\%) was lower in all of six experimental fish groups. The reason might be due to the difference in dietary garlic utilization between garlic extract and GP and to the difference in fish size between previous (65 to $250 \mathrm{~g}$ ) and present (5 to $30 \mathrm{~g}$ ) studies. As well, it might be suggested that fingerling sterlet sturgeon utilize protein more than lipid in their diet.

In conclusion, broken-line regression model analysis and second order polynomial regression model analysis relation on the basis of SGR and WG indicated that the dietary optimal GP level could be greater than $1.77 \%$ and $1.79 \%$, but less than $2.95 \%$ and $3.18 \%$ in fingerling sterlet sturgeon. The present results suggest that dietary garlic for fingerling sterlet sturgeon (5.5 to $30.0 \mathrm{~g}$ ) could positively affect growth performance and feed utilization.

\section{ACKNOWLEDGMENTS}

We would like to thank Gyeonggi Province Maritime and Fisheries Research Institute for donating the fish and providing the facility.

\section{REFERENCES}

Abou-Zeid, S. M. 2002. The Effect of Some Medical Plant on Reproductive and Productive Performance of Nile tilapia Fish. Ph.D. Thesis, Cairo University, Faculty of Agriculture. Cairo, Egypt. p. 212.

Abdel-Hakim, N. F., M. M. E. Lashin, A. A. M. Al-Azab, and A. M. Ashry. 2010. Effect of fresh or dried garlic as a natural feed supplement on growth performance and nutrients utilization of the Nile Tilapia (Oreochromis niloticas). Egypt J. Aquat. Biol. Fish 14:19-38.

Agarwal, K. C. 1996. Therapeutic actions of garlic constituents. Med. Res. Rev. 16:111-124.

Agusti, K. T. 1996. Therapeutic values of onion (Allium cepa L) and garlic (Allium sativum L). Indian J. Exp. Biol. 34:634-640.

Al-Salahy, M. B. and A. A. B. Mahmoud. 2003. Metabolic and 
histological studies on the effect of garlic administration on the carnivorous fish Chrysichthys auratus. Egypt J. Bot. 5:94-107.

AOAC. 1995. Official Methods of Analysis. 16th ed. Association of Official Analytical Chemists. Arlington, VA, USA.

Bampidis, V. A., V. Christodoulou, E. Christaki, P. Florou-Paneri, and A. B. Spais. 2005. Effect of dietary garlic bulb and garlic husk supplementation on performance and carcass characteristics of growing lambs. Anim. Feed Sci. Technol. 121:273-283.

Bhosale, S. V., M. P. Bhilave, and S. B. Nadaf. 2010. Formulation of Fish Feed using Ingredients from Plant Sources. Res. J. Agric. Sci. 1:284-287.

Bordia, A., S. K. Verma, and K. C. Srivastava. 1996. Effect of garlic on platelet aggregation in humans: A study in healthy subjects and patients with coronary artery disease. Prostoglandins Leukot. Essent. Fatty Acids 55:201-205.

Chi, M. S., E. T. Koh, and T. J. Steward. 1982. Effects of garlic on lipid metabolism in rats fed cholesterol or lard. J. Nutr. 112:241-248.

Citarasu, T., M. M. Babu., S. M. J. Punitha., K. Venket Ramalingam, and M. P. Marian. 2001. Control of pathogenic bacteria using herbal biomedical products in the larva culture system of Penaeus monodon. International Conference on Advanced Technologies in Fisheries and Marine Sciences. M. S. University. Tirunelveli, India. 104 p.

Citarasu, T., R. R. Sekar, M. M. Babu, and M. P. Marian. 2002. Developing artemia enriched herbal diet for producing quality larvae in Penaeus monodon. Asian Fish. Sci. 15:21-32.

Citarasu, T. 2010. Herbal biomedicines: a new opportunity for aquaculture industry. Aquacult. Int. 18:403-414.

Diab, A. S., G. O. El-Nagar, and Y. M. Abd-El-Hady. 2002. Evaluation of Nigella sativa L (black seeds; baraka), Allium sativum (garlic) and BIOGEN as feed additives on growth performance and immunostimulants of $O$. niloticus fingerlings. Suez Canal Vet. Med. J. pp. 745-775.

Duncan, D. B. 1955. Multiple range and multiple ' $F$ ' tests. Biometrics 11:1-42.

El-Dakar, A. Y., G. D. I. Hassanien, S. S. Gad, and S. E. Sakr. 2004a. Use of medical and aromatic plants in fish diets: I. Effect of dried marjoram leaves on performance of hybrid tilapia Oreochromis niloticus $\times$ Oreochromis auraus, fingerlings. J. Egypt. Acad. Soc. Environ. Dev. (B. Aquacult.). 5:67-83.

El-Dakar, A. Y., G. D. I. Hassanien, S. S. Gad, and S. E. Sakr. 2004b. Use of medical and aromatic plants in fish diets: 2. Effect of dried basil leaves on performance of hybrid tilapia Oreochromis niloticus $\times$ Oreochromis auraus, fingerlings. 3rd Inter. Conf. on Animal Production and Health in Semi-Arid Areas. Suez Canal University, Suez Canal, Egypt. pp. 265-277.

Fernández-Navarro, M., J. Peragón, F. Esteban, M. Higuera, and J. A. Lupiáñez. 2006. Maslinic acid as a feed additive to stimulate growth and hepatic protein-turnover rates in rainbow trout (Onchorhynchus mykiss). Comp. Biochem. Physiol. C. Toxicol. Pharmacol. 144:130-140.

Foushee, D. B., J. Ruffin, and U. Banerjee. 1982. Garlic as a natural agent for the treatment of hypertension: A preliminary report. Cytobios. 34:145-152.

Freitas, R., J. B. Fonseca, R. T. Soares, H. S. Rostagn, and P. R. Soares. 2001. Utilization of garlic (Allium sativum L.) as growth promoter of broilers. Rev. Bras. Zootec. 30:761-765.
Horton, G. M. J., D. B. Blethen, and B. M. Prasad. 1991. The effect of garlic (Allium sativum) on feed palatability of horses and feed consumption, selected performance, and blood parameters in sheep and swine. Can. J. Anim. Sci. 71:607-610.

Hung, S. S. O., F. S. Conte, and F. Frost. 1998. Growth of white sturgeon fed seven commercial feeds. Aquaculture 161:89-93.

Jayaprakas, V. and J. Eupharsia. 1996. Growth performance of Labeo rohita (Ham.) Livol (IHF-1000) an herbal product. Proc. Indian Natl. Sci. Acad. 63:1-10.

Jegede, T. 2012. Effect of garlic (Allium sativum) on growth, nutrient utilization, resistance and survival of Tilapia zillii (Gervais 1852) Fingerlings. J. Agricult. Sci. 4:269-274.

Khalil, R. H., B. M. Nadia, and M. K. Soliman. 2001. Effects of Biogen and Levamisol $\mathrm{Hcl}$ on the immune response of cultured Oreochromis niloticus to Aeromonas hydrophila vaccine. Beni-Suef Vet. Med. J., Egypt, XI(2):381-392.

Khattab, Y. A., A. M. S. Shalaby, S. M. Sharaf, H. I. EL-Marakby, and E. H. Rizhalla. 2004. The physiological changes and growth performance of the Nile tilapia Oerochromis niloticus after feeding with Biogen ${ }^{\circledR}$ as growth promoter. Egypt $\mathrm{J}$. Aquatic. Biol. Fish 8:145-158.

Krayushkina, L. S. 2006. Considerations on evolutionary mechanisms of osmotic and ionic regulation in Acipenseridae: An overview. J. Appl. Ichthyol. 22:70-76.

Lee, D. H., C. S. Ra, Y. H. Song, K. I. Sung, and J. D. Kim. 2012. Effect of dietary garlic extracts on growth, feed utilization and whole body composition of juvenile sterlet sturgeon (Acipenser ruthenus). Asian Australas. J. Anim. Sci. 25:577583.

Lim, S. R. 2009. The Optimum Dietary Protein Level and the Optimum Protein to Energy Ratio in Sterlet Sturgeon, Acipenser ruthenus. Ph.D. Thesis. Pukyong National University, Busan, Korea. pp. 82-85.

Macmahon, F. G. and R. Vargus. 1993. Can garlic lower blood pressure. A pilot study. Pharmacotherapy 13:406-407.

Metwally, M. A. A. 2009. Effects of garlic (Allium sativum) on some antioxidant activities in tilapia nilotica (Oreochromis niloticus). World J. Fish Mar. Sci. 1:56-64.

Nya, E. J. and B. Austin. 2009. Use of garlic, Allium sativum, to control Aeromonas hydrophila infection in rainbow trout, Oncorhynchus mykiss (Walbaum). J. Fish Dis. 32:963-970.

Pait, A. S. and J. O. Nelson. 2003. Vitellogenesis in male Fundulus heteroclitus (Killifish) induced by selected estrogenic compounds. Aquat. Toxicol. 64: 331-342.

Robbins, K. R., H. W. Norton, and D. H. Baker. 1979. Estimation of nutrient requirements from growth data. J. Nutr. 109:17101714.

Sahu, S., B. K. Das, B. K. Mishra, J. Pradhan, and N. Sarangi. 2007. Effect of Allium sativum on the immunity and survival of Labeo rohita infected with Aeromonas hydrophila. J. Appl. Ichthyol. 23:80-86.

Shalaby, A. M., Y. M. Khattab, and A. M. Abdel rahman. 2006. Effects of garlic (Allium sativum) and chloramphenicol on growth performance, physiological parameters and survival of Nile Tilapia (Oreochromis niloticus). J. Venom. Anim. Toxins incl. Trop. Dis. 12:172-201.

Shalaby, S. M. M. 2004. Response of Nile tilapia, Oreochromis niloticus, fingerlings to diets supplemented with different levels of fenugreek seeds (Hulba). J. Agric. Mansoura Univ. 
29:2231-2242.

Shalaby, S. M. M., A. I. Abd Elmonem, and A. Y. El-Dakar. 2003. Enhancement of growth performance, feed and nutrient utilization of nile tilapia (Oreochromis niloticus), using of licorice roots (Erksous) as a feed attractive. J. Egypt. Acad. Soc. Environ. Develop. (B-Aquaculture), 4:119-142.

Shin, S. H. and M. K. Kim. 2004. Effect of dried powders or ethanol extracts of garlic flesh and peel on lipid metabolism and antithrombiogenic capacity in 16-month-old rats. J. Nutr. Health. 37:515-524.

Sivaram, V., M. M. Babu, G. Immanuel, S. Murugadass, T. Citarasu, and M. P. Marian. 2004. Growth and immune response of juvenile greasy groupers (Epinephelus tauvina) fed with herbal antibacterial active principle supplemented diets against Vibrio harveyi infections. Aquaculture 237:9-20.

Soltan, M. A. and S. M. El-Laithy. 2008. Effect of probiotics and some spices as feed additives on the performance and behaviour of the Nile tilapia, Oreochromis niloticus. Egypt. J. Aquat. Biol. Fish. 12:63-80.
SPSS. Inc. 1999. SPSS Base 10.0 for Windows User's Guide. SPSS Inc. Chicago, IL, USA.

Tatara, M. R., E. Sliwa, K. Dudek, A. Gawron, and T. Piersiak. 2008. Aged garlic extract and allicin improve performance and gastrointestinal tract development of piglets reared in artificial sow. Ann. Agric. Environ. Med. 15:63-69.

Wanapat, M., P. Khejornsart, P. Pakdee, and S. Wanapat. 2008. Effect of supplementation of garlic powder on rumen ecology and digestibility of nutrients in ruminants. J. Sci. Food Agric. 88:2231-2237.

Yeh, Y. Y. and L. Liu. 2001. Cholesterol-Lowering effect of garlic extracts and organosulfur compounds: Human and animal studies. J. Nutr. 131:9895-9935.

Zeitoun, I. H., D. E. Ullrey, D. E. Magae, J. L. Gill, And W. G. Bergen. 1976. Quantifying nutrient requirements of fish. Journal of the Fisheries Research Board of Canada. 33:167172. 